\title{
C-Section Prevalence Among Obese Mothers and Neonatal Hypoglycemia: a Cohort Analysis of the Department of Gynecology and Obstetrics of the University of Lübeck
}

\section{Prävalenz von Sectiones von adipösen Müttern und neonatale Hypoglykämie: eine Kohortenstudie der universitären Frauenklinik Lübeck}

Authors

Kay Neumann ${ }^{1}$, Ineke Indorf ${ }^{1}$, Christoph Härtel ${ }^{2}$, Christoph Cirkel ${ }^{1}$, Achim Rody ${ }^{1}$, Daniel A. Beyer ${ }^{3}$

\section{Affiliations}

1 Department of Obstetrics and Gynecology, SchleswigHolstein University, Campus Lübeck, Lübeck, Germany

2 Department of Department of Pediatrics and Child Health, Schleswig-Holstein University, Campus Lübeck, Lübeck, Germany

3 Westpfalz-Klinikum GmbH, Kaiserslautern, Germany

Key words

adiposity, obesity, mode of delivery, pregnancy, neonatal outcome

Schlüsselwörter

Adipositas, Geburtsmodus, Schwangerschaft, neonatales Outcome

received 17.2.2017

revised $\quad 8.4 .2017$

accepted 9.4.2017

\section{Bibliography}

DOI https://doi.org/10.1055/s-0043-108763

Geburtsh Frauenheilk 2017; 77: 487-494 @ Georg Thieme

Verlag KG Stuttgart · New York | ISSN 0016-5751

\section{Correspondence}

Dr. med. Kay Neumann

Department of Obstetrics and Gynecology, Section of Gynecological Endocrinology and Reproductive Medicine Schleswig-Holstein University, Campus Lübeck Ratzeburger Allee 160, 23538 Lübeck, Germany

Kay.Neumann@uksh.de

\section{ABSTRACT}

Introduction Data from the World Health Organization (WHO) demonstrates an increasing prevalence of obesity in Western countries. This study investigates the influence of obesity on the mode of delivery and the occurrence of hypoglycemia in newborns.

Materials and Methods A retrospective analysis of all deliveries at the Department of Gynecology and Obstetrics of the University of Lübeck, Germany was conducted over a period of eleven years with the primary outcome as non-elective Csections and hypoglycemia of newborns from obese mothers. Patients were divided into six subgroups according to WHO weight classifications as follows: control group body mass index (BMI) 18.5-24.9 kg/m², $\mathrm{n}=7712$; general obesity BMI $\geq 25 \mathrm{~kg} / \mathrm{m}^{2}, \quad \mathrm{n}=4227$; overweight BMI $25-29.9 \mathrm{~kg} / \mathrm{m}^{2}$, $\mathrm{n}=2628$; obesity I $\mathrm{BMI} 30-34.9 \mathrm{~kg} / \mathrm{m}^{2}, \mathrm{n}=1017$; obesity $\mathrm{II}^{\circ}$ BMI $35-39.9 \mathrm{~kg} / \mathrm{m}^{2}, \mathrm{n}=370$; obesity $\quad \mathrm{II}^{\circ} \mathrm{BMI} \geq 40 \mathrm{~kg} / \mathrm{m}^{2}$, $\mathrm{n}=212$.

Results Analysis of the primary outcome shows an increased incidence of non-elective C-sections with an elevated BMI (general obesity vs. control group: 20.5 vs. $15.9 \%, p<0.001$; OR 1.3; $95 \% \mathrm{Cl} 1.2-1.4$ ) and elevated rates of neonatal hypoglycemia in newborns of obese mothers (general obesity vs. control group: 0.6 vs. $0.3 \%, \mathrm{p}<0.05$; OR 1.8 ; $95 \% \mathrm{Cl} 1.0-3.0$ ). Conclusions Obesity is an essential obstetric risk factor. Obese women face an increased risk of non-elective C-sections, and newborns of obese mothers suffer from elevated rates of hypoglycemia.

\section{ZUSAMMENFASSUNG}

Einleitung Nach Daten der Weltgesundheitsorganisation (WHO) steigt die Prävalenz von Adipositas in westlichen Ländern. Die vorliegende Studie untersucht den Einfluss von Adipositas auf den Geburtsmodus sowie auf die Hypoglykämierate der Neugeborenen.

Material und Methoden Retrospektive Kohortenanalyse aller Geburten ( $n=17205$ ) der Universitätsfrauenklinik zu Lübeck im Zeitraum von 11 Jahren. Primäres Zielkriterium: Rate an sekundären Sectiones (= nicht elektiven Sectiones) und Hypoglykämierate von Neugeborenen adipöser Mütter. Einteilung der Patientinnen in 6 verschiedene Subgruppen analog der WHO-Gewichtsklassifikation (Kontrollgruppe BMI 18,5$24,9 \mathrm{~kg} / \mathrm{m}^{2}, \mathrm{n}=7712$, allgem. Übergewichtige BMI $\geq 25 \mathrm{~kg} /$ $\mathrm{m}^{2} \mathrm{n}=4227$, sowie nach WHO Präadipositas BMI $25-29,9 \mathrm{~kg} /$ $\mathrm{m}^{2} \mathrm{n}=2628$, Adipositas I ${ }^{\circ} \mathrm{BMI} 30-34,9 \mathrm{~kg} / \mathrm{m}^{2} \mathrm{n}=1017$, II $^{\circ} \mathrm{BMI}$ 
35-39,9 $\mathrm{n}=370, \quad$ III $\mathrm{BMI} \geq 40 \mathrm{n}=212$ ) mit anschließendem Vergleich bezüglich der definierten Outcomeparameter.

Ergebnisse Ein Vergleich der Geburtsmodi zeigt eine steigende Häufigkeit einer sekundären Sectio mit zunehmendem Body-Mass-Index (allgem. Übergewichtige vs. Kontrollgruppe 20,5 vs. $15,9 \%, p<0,001$; OR 1,3; 95\%-KI 1,2-1,4). Zudem zeigte sich eine erhöhte Rate an fetalen Hypoglykämien im adipösen Kollektiv (allgem. Übergewichtige vs. Kontrollgruppe 0,6 vs. 0,3\%, p<0,05; OR 1,8; 95\%-KI 1,0-3,0).

Diskussion Adipositas stellt einen wesentlichen geburtshilflichen und neonatalen Risikofaktor dar. Ein erhöhter mütterlicher BMI senkt die Wahrscheinlichkeit für einen Spontanpartus und das Risiko für kindliche Hypoglykämien nimmt zu.

\section{Abbreviations}

$\begin{array}{ll}\text { BMI } & \text { body mass index } \\ \text { CTG } & \text { cardiotocography } \\ \text { GDM } & \text { gestational diabetes } \\ \text { i.a. } & \text { inter alia } \\ \text { IUGR } & \text { intrauterine growth restriction } \\ \text { e.g. } & \text { for example } \\ \text { OR } & \text { odds ratio } \\ \text { MV } & \text { mean value } \\ \text { SD } & \text { standard deviation } \\ \text { vs. } & \text { versus } \\ \text { PIH } & \text { pregnancy-induced hypertension }\end{array}$

\section{Introduction}

In Western countries, modification of lifestyle has caused an increased incidence of an overweight (body mass index [BMI] 25$29.9 \mathrm{~kg} / \mathrm{m}^{2}$ ) or obese (BMI $\geq 30 \mathrm{~kg} / \mathrm{m}^{2}$ ) status within the population [1,2]. Especially in Germany, the number of obese patients has increased inter alia (i.a.) at maternity clinics (2008-2011: prevalence of pregnant obese women $23.9 \%$ ), which creates challenges for midwives and gynecologists during their daily routine [3]. International studies i. a. from Sweden [4], Great Britain [5], Turkey [6] and Israel [7] investigated the influence of overweight status on pregnancy and delivery. These studies indicated elevated risks for pregnancies and deliveries of obese women such as neonatal hypoglycemia which requires immediate care $[8,9]$. Arrowsmith et al. 2011 found in a British collective of obese women more inductions of labor and increased C-sections rates $(28.4 \%$ vs. $18.9 \%$ for a BMI $>30 \mathrm{~kg} / \mathrm{m}^{2}$ vs. BMI $20-24.9 \mathrm{~kg} / \mathrm{m}^{2}$ ) but no increase in preterm deliveries despite increased complications of pregnancies of obese women [10]. As possible explanation poor contractility due to less $\mathrm{Ca}^{2+}$ flux of myometrium from obese women was suggested [11]. In addition, further possible explanations for poor uterine contractility of obese women might be greater oxytocin utilization [12], prostaglandin E2 insensitivity [13] and disturbed reactive oxidative species homeostasis [1416].

An international systematic review analyzing eleven studies regarding obesity and mode of delivery showed an odds ratio (OR) for C-sections ranging from OR 1.53 (BMI $25-30 \mathrm{~kg} / \mathrm{m}^{2}$ ) to OR 3.38 (Obesity $\mathrm{I}^{\circ}-\mathrm{II}^{\circ}$, BMI $>35 \mathrm{~kg} / \mathrm{m}^{2}$ ) vs. non-obese women (BMI $\left.18-25 \mathrm{~kg} / \mathrm{m}^{2}\right)$ [17].
However, there are many differences between countries concerning prenatal care, obstetric management and postnatal care of newborns. Therefore, this study investigated the influence of an elevated BMI on the mode of delivery (primary outcome: nonelective C-sections) and on the occurrence of hypoglycemic newborns in a German University hospital.

\section{Materials and Methods}

This study was approved by the ethical board of the University of Lübeck, Germany, (registration number 11-183). For this study, all deliveries $(n=17205)$ at the Department of Obstetrics and Gynecology at the University Hospital of Lübeck were analyzed in a period of 11 years.

\section{Inclusion and exclusion criteria}

To avoid confounding, exclusions criteria were defined as BMI $<18.5 \mathrm{~kg} / \mathrm{m}^{2}(\mathrm{n}=519)$, patient height below $1.5 \mathrm{~m}(\mathrm{n}=26)$ (to avoid increased BMI because of small height), and patients with multiple pregnancies $(n=4122)$ (to prevent indication for C-section due to previous $\mathrm{C}$-sections and to avoid potential confounding due to a previous successful vaginal delivery). Additionally, for the analysis of the mode of delivery, deliveries < 34th week of gestation were excluded to avoid confounding factors due to gestational age. For accurate analysis, patients with incomplete data $(n=599)$ were excluded from this study as well. $>$ Fig. 1 shows a flowchart of included patients.

\section{Classification of obesity}

Obesity was classified using weight at delivery which was the last documented weight of prenatal care. The BMI classification system from the WHO was used. Consequently, six different subgroups were formed, retrospectively:

1. control group: BMI $18.5-24.9 \mathrm{~kg} / \mathrm{m}^{2}, \mathrm{n}=7712$

2. general obesity: $\mathrm{BMI} \geq 25 \mathrm{~kg} / \mathrm{m}^{2}, \mathrm{n}=4227$

3. overweight: BMI $25-29.9 \mathrm{~kg} / \mathrm{m}^{2}, \mathrm{n}=2628$

4. obesity I : BMI $30-34.9 \mathrm{~kg} / \mathrm{m}^{2}, \mathrm{n}=1017$

5. obesity $I^{\circ}$ : BMI $35-39.9 \mathrm{~kg} / \mathrm{m}^{2}, \mathrm{n}=370$

6. obesity $\mathrm{II}^{\circ}: \mathrm{BMI} \geq 40 \mathrm{~kg} / \mathrm{m}^{2}, \mathrm{n}=212$

\section{Outcome parameters: C-sections and neonatal hypoglycemia}

All deliveries were analyzed for the main parameter of a non-elective C-section. A non-elective C-section was defined as a C-section that was performed due to indications from the course of delivery in order to avoid maternal or fetal threats. 


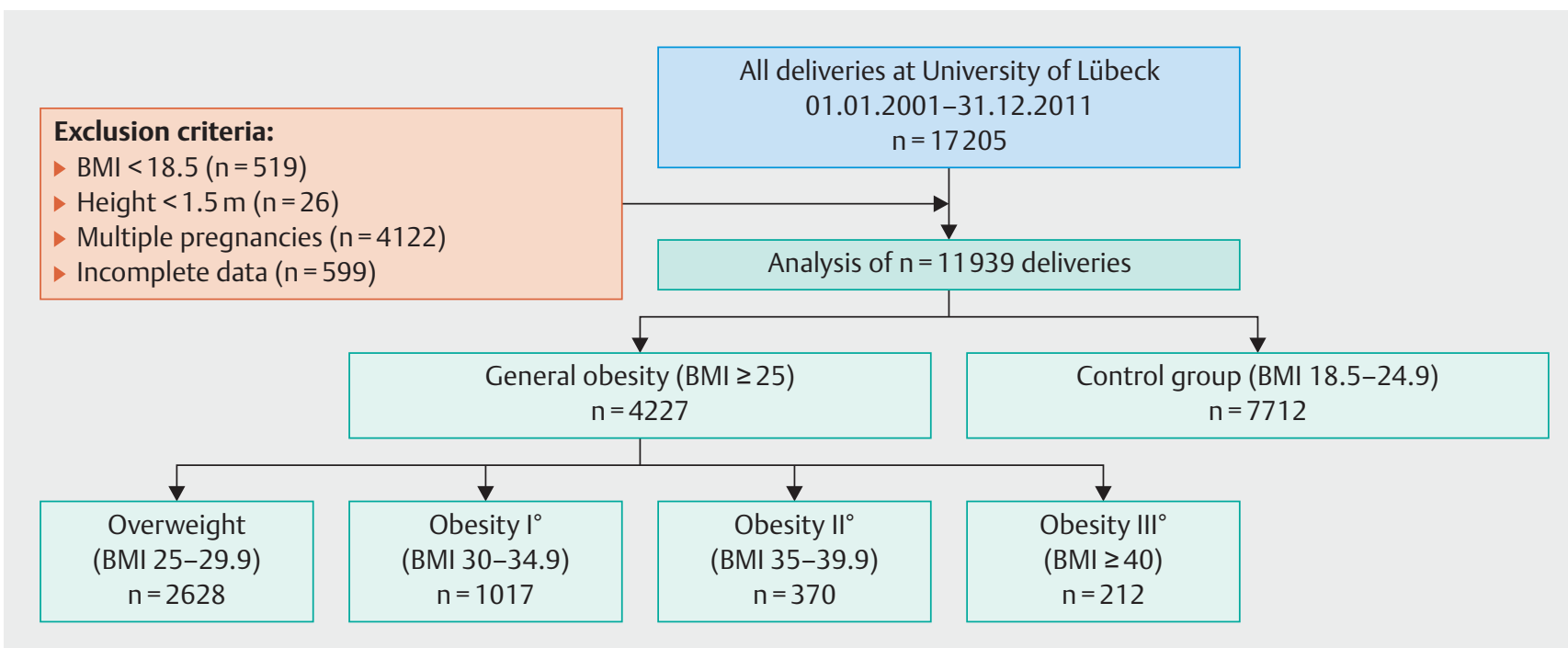

- Fig. 1 Flowchart of patients.

Furthermore, the rate of hypoglycemia of newborns was investigated. Hypoglycemia was defined as blood glucose $<45 \mathrm{mg} / \mathrm{dl}$ $24 \mathrm{~h}$ postnatal. Hypoglycemia of newborns were determined using capillary blood samples which where collected $2 \mathrm{~h}$ postnatal according to AWMF guidelines [18].

Fetal macrosomia was diagnosed for birth weights $>90$ th percentile according to the percentiles from Voigt M 2004 [19]. A birth weight $<10$ th percentile in combination with a pathologic umbilical arterial blood flow was considered as an intrauterine growth restriction (IUGR).

Additionally, to gain an overview of patient characteristics, the data concerning demography, pregnancy-related concomitant diseases, perinatal management and complications of newborns were analyzed.

\section{Statistical analyses}

For data collection, the software ViewPointFetal Database (GE Healthcare, Chicago, Illinois, United States) was used. Statistical analysis was done using the software SPSS 21.0. The Mann-Whitney U-test was used for independent, non-normally distributed parameters.

Analysis included the Mann-Whitney $U$ test for continuous data, the $x^{2}$ test for categorical data and Fisher's exact t-test.

Multivariate regression analysis was used to investigate the independence of mode of delivery from maternal age $=X_{1}$, maternal height $=X_{2}$, Origin $=X_{3}$, Smoking $=X_{4}$, multiparity $=X_{5}$, preeclampsia $=X_{6}$, pregnancy-induced hypertension $=X_{7}$, and gestational diabetes $=X_{8}$. Mode of delivery was defined as non-elective $\mathrm{C}$-sections $=\mathrm{Y}$. The statistical performance was calculated with the Omnibus test/likelihood-ratio test using no non-elective Csections as a reference.

To investigate independence of the hypoglycemia parameter of newborns from gestational diabetes $\mathrm{X}={ }_{1}$ and $\mathrm{C}$-section $\mathrm{X}={ }_{2}$, a multivariate regression analysis was used. Euglycemia was used as a reference. Statistical significance was considered at $p<0.05$.
Statistical analysis was supported by Prof. Koenig, Institute of Medical Biometry and Statistics, University of Lübeck, Germany.

\section{Results}

\section{Patient characteristics}

In this study, the data from 17205 patients were analyzed, and 11939 patients were included. The mean BMI of all patients was $24.7171 \mathrm{~kg} / \mathrm{m}^{2}$ (standard deviation [SD] \pm 5.04 ). There was no Gaussian distribution of the BMI data, which are shown in - Fig. 2 (Kolmogorov-Smirnov test < $0.05 \%$ ). The mean age of patients at delivery was 29.94 years (SD \pm 6 years, $14-49$ years). Statistical analysis showed independence of BMI from age of patients. Mean height was 1.68 meter (SD $\pm 0.06 \mathrm{~m}$ ). Most women were of Caucasian ethnicity (82.6\%), a minority has an eastern European origin (5.9\%). 47.9\% of all included women were married (no statistical difference between all groups).

Obese patients smoked more often > 10 cigarettes/day (general obesity versus [vs.] control group) and suffered more often from pre-existing concomitant diseases (diabetes mellitus I/II 11.3 vs. $3.8 \%, p<0.001$; arterial hypertension 6.1 vs. $3.4 \%$, $\mathrm{p}<0.001$; and additional unspecific chronic diseases 19.1 vs. $15.1 \%, p<0.001)$. In addition to pre-existing diseases, obese women more often developed pregnancy-related diseases than the control group (gestational diabetes [GDM] 9.5 vs. 4.5\%, $\mathrm{p}<0.001$; pregnancy-induced hypertension $[\mathrm{PIH}] 6.1$ vs. 1.4 , $\mathrm{p}<0.001$; HELLP syndrome 1.5 vs. $0.9 \%, \mathrm{p}<0.05$; pre-eclampsia 4.8 vs. $2.0 \%, \mathrm{p}<0.001$; placental dysfunction 4.7 vs. $3.3 \%$, $\mathrm{p}<0.001)$. For detailed data see $>$ Table 1.

\section{Mode of delivery of obese women}

Analysis of the main outcome parameter, non-elective C-sections, revealed that obese women face higher risks for non-elective C-sections (general obesity vs. control group 20.5 vs. $15.9 \%$, 


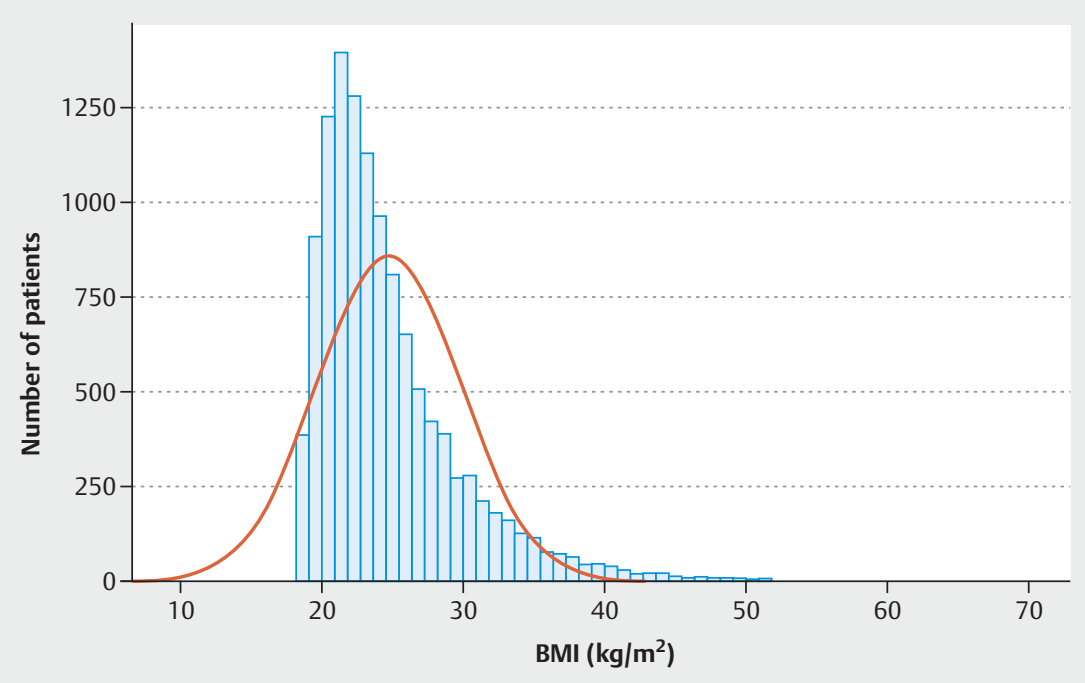

- Fig. 2 Histogram of BMI of included patients.

- Table 1 Pregnancy-related concomitant diseases of different groups of obesity.

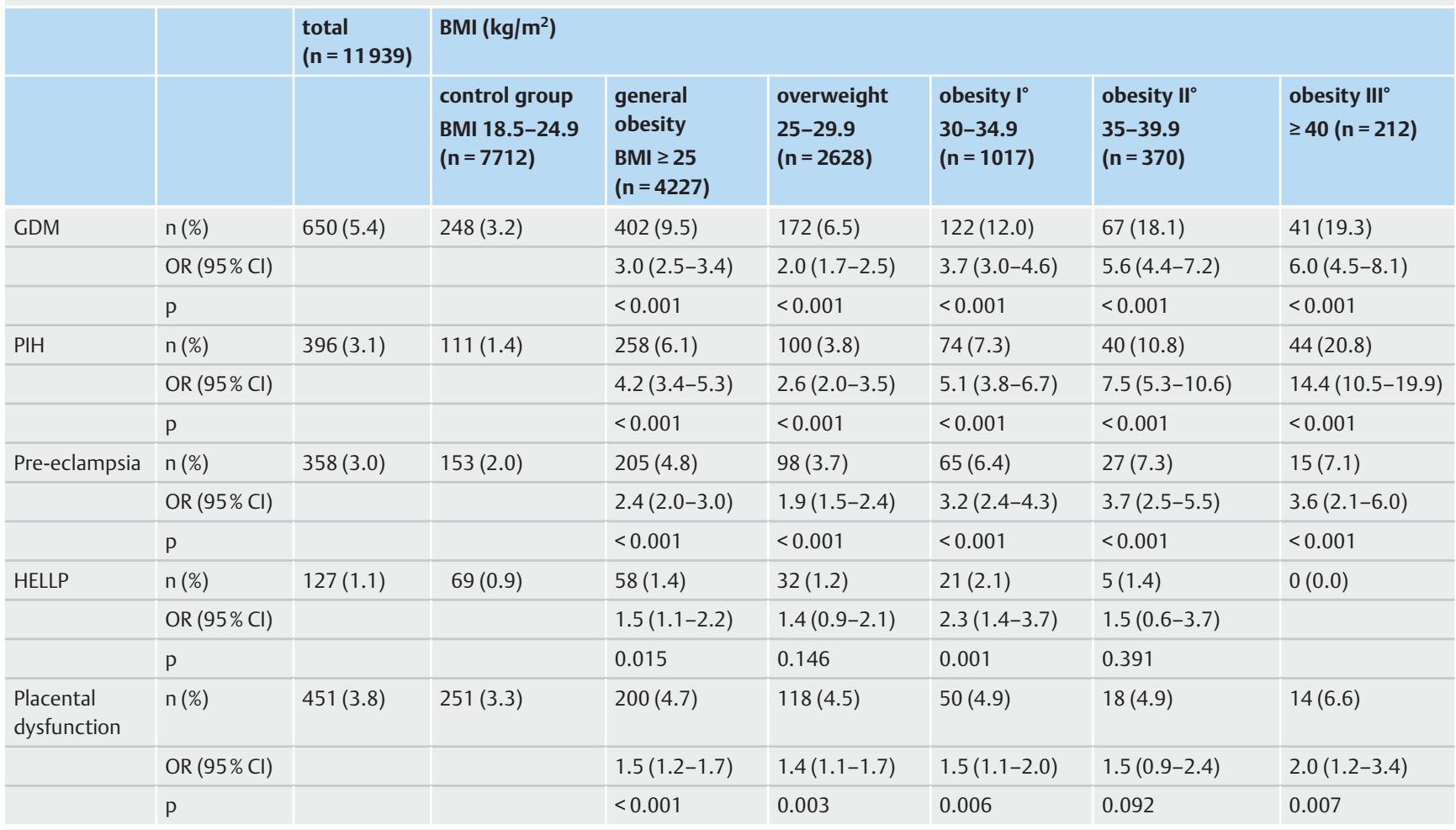

P-values compare each group of obesity vs. control group.

$\mathrm{GDM}=$ gestational diabetes, $\mathrm{OR}=$ odds ratio, $\mathrm{MV}=$ mean value, $\mathrm{PIH}=$ pregnancy-induced hypertension 


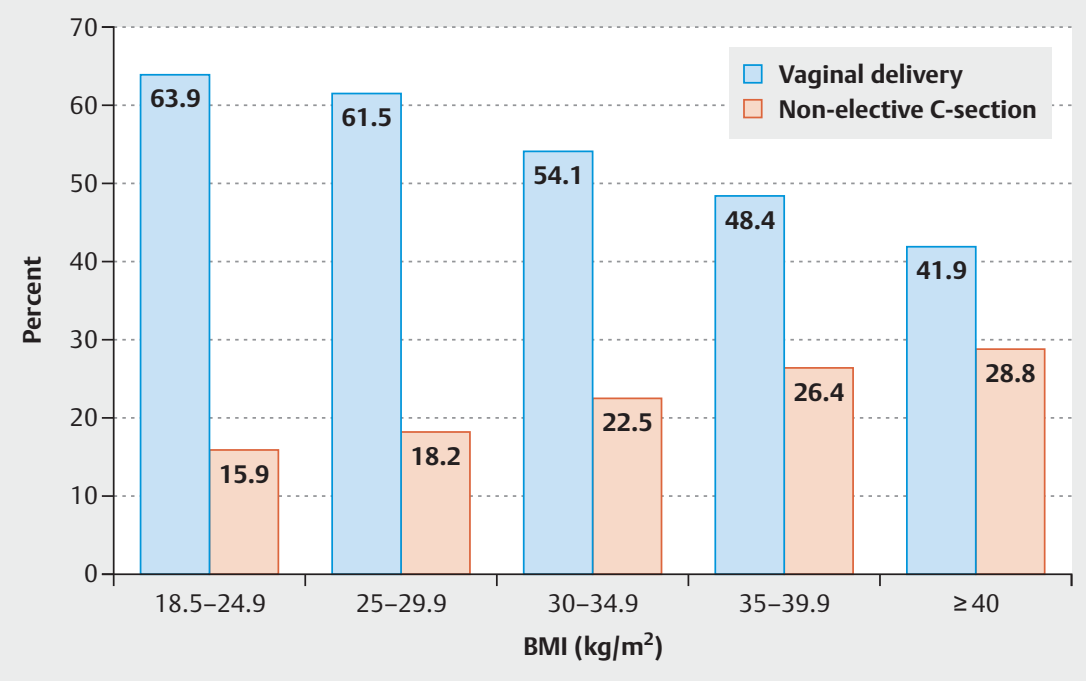

- Fig. 3 Mode of delivery of obese and non-obese women.

$\mathrm{p}<0.001)$ and pathological cardiotocography (CTG) (7.5 vs. $5.8 \%$, $\mathrm{p}<0.001)$. Fig. 3 displays an elevation of non-elective C-sections depending on BMI.

In addition, elective C-sections were elevated in obese women (general obesity vs. control group 18.1 vs. $15.8 \%$, p < 0.05 ). Accordingly, obese women had a lower chance of a successful vaginal delivery than women in the control group (general obesity vs. control group 57.5 vs. 63.9\%, p<0.001). Obese women who could deliver spontaneously suffered from increased injuries from birth (perineal lacerations: general obesity vs. control group 27.7 vs. $23.3 \%, p<0.001$ ). Furthermore, obese women had to receive more inductions of labor than the control group (26.6 vs. $18.7 \%$, $\mathrm{p}<0.001)$.

Conversely, there was no difference in gestational week or preterm delivery between all groups. For detailed data see $\mathbf{\bullet}$ Table $\mathbf{2}$.

A multivariate regression analysis showed an increased incidence of hypoglycemia for newborns of obese women (general obesity vs. control group 0.6 vs. $0.3 \%, p<0.05$ ). Hence, newborns of obese mothers had to be admitted more often to neonatal care unit (general obesity vs. control group 20.9 vs. $18.9 \%$, $p<0.05$ ).

Furthermore, newborns were more often macrosomal (general obesity vs. control group 1.6 vs. $0.8 \%, p<0.001)$ or showed intrauterine growth restriction ( 4.3 vs. $3.5 \%, p<0.05$ ).

Despite fetal macrosomia being an essential risk factor for shoulder dystocia, there was no significant difference for this obstetric emergency between all groups (general obesity vs. control group 1.35 vs. $0.99 \%, p=0.583$ ). There was a statistical equal distribution of newborns sex between all groups.

For further data concerning Apgar values, venous umbilical cord-pH, stillbirth and malformation, see $>$ Table 3.

\section{Discussion}

In this study, the prevalence of an overweight (BMI $25-29.9 \mathrm{~kg} /$ $\mathrm{m}^{2}$ ) and obese I (BMI: $30-34.9 \mathrm{~kg} / \mathrm{m}^{2}$ ) status was $22.0 \%$ (overweight) and $13.4 \%$ (obesity $I^{\circ}$ ) which is in line with the data from the Robert Koch Institute for Germany [8]. Obesity does not only appear as an isolated factor in this study, it is also combined with an unhealthy lifestyle. Thus, obese women smoke more often (even in pregnancy) and suffer from concomitant diseases of obesity (diabetes mellitus I/II, arterial hypertension). Moreover, the prevalence of gestational diabetes is elevated in obese women in this study (OR 3.0 with $\mathrm{BMI}>25 \mathrm{~kg} / \mathrm{m}^{2}$ ). Therefore, this study underlines the need for consequent screening for gestational diabetes in obese women.

This study found a $40 \%$ increase in non-elective C-sections in women with a BMI $>30 \mathrm{~kg} / \mathrm{m}^{2}$. Obese women who were able to deliver spontaneously suffered from more perineal lacerations which is in line with previous investigations [20].

The finding of elevated C-section rates in obese women was postulated by previous studies [21-23]. However, these studies did not differentiate between elective and non-elective C-sections, which is necessary for comparison of risks of delivery.

The elevation of non-elective C-sections in this study might be caused by the increase in pathological CTGs of obese women, which was revealed after further analysis. An enlarged abdominal girth can aggravate the acquisition of CTG patterns during routine clinical exams, which potentiates the danger of missing pathological CTGs of obese women.

Many studies [24] have demonstrated the disadvantages of C-sections vs. spontaneous vaginal delivery, such as specific risks of the operation (bowel violation, bladder violation, perioperative bleeding, etc.) or impairment of wound healing, which is espe- 
- Table 2 Mode of delivery of different groups of obesity.

\begin{tabular}{|c|c|c|c|c|c|c|c|c|}
\hline & & \multirow[t]{2}{*}{ Total } & \multicolumn{6}{|l|}{ BMI $\left(\mathrm{kg} / \mathrm{m}^{2}\right)$} \\
\hline & & & $\begin{array}{l}\text { Control group } \\
\text { BMI } \\
18.5-24.9\end{array}$ & $\begin{array}{l}\text { General obesity } \\
\mathrm{BMI} \geq 25\end{array}$ & $\begin{array}{l}\text { Overweight } \\
25-29.9\end{array}$ & 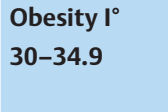 & $\begin{array}{l}\text { Obesity } 11^{\circ} \\
35-39.9\end{array}$ & $\begin{array}{l}\text { Obesity } 1 \mathrm{II}^{\circ} \\
\geq 40\end{array}$ \\
\hline \multirow[t]{3}{*}{ Non elective C-section } & $n(\%)$ & $1921(17.5)$ & $1129(15.9)$ & $792(20.5)$ & $437(18.2)$ & $208(22.5)$ & $90(26.4)$ & $57(28.8)$ \\
\hline & OR $(95 \% \mathrm{Cl})$ & & & $1.3(1.2-1.4)$ & $1.1(1.0-1.3)$ & $1.4(1.2-1.6)$ & $1.7(1.4-2.0)$ & $1.8(1.4-2.3)$ \\
\hline & $\mathrm{p}$ & & & $<0.001$ & 0.008 & $<0.001$ & $<0.001$ & $<0.001$ \\
\hline \multirow[t]{3}{*}{ Elective C-section } & $n(\%)$ & $1819(16.6)$ & $1121(15.8)$ & $698(18.1)$ & $392(16.3)$ & $179(19.4)$ & $73(21.4)$ & $54(27.3)$ \\
\hline & OR $(95 \% \mathrm{Cl})$ & & & $1.1(1.1-1.2)$ & $1.0(0.9-1.2)$ & $1.2(1.1-1.4)$ & $1.4(1.1-1.7)$ & $1.7(1.4-2.2)$ \\
\hline & $\mathrm{P}$ & & & 0.002 & 0.512 & 0.005 & 0.005 & $<0.001$ \\
\hline \multirow[t]{3}{*}{ Vaginal delivery } & $n(\%)$ & $6770(61.7)$ & 4547 (63.9) & $2223(57.5)$ & $1476(61.5)$ & $499(54.1)$ & $165(48.4)$ & 83 (41.9) \\
\hline & OR $(95 \% \mathrm{Cl})$ & & & $0.9(0.9-0.9)$ & $1.0(0.9-1.0)$ & $0.8(0.8-0.9)$ & $0.08(0.7-0.8)$ & $0.7(0.6-0.8)$ \\
\hline & $\mathrm{p}$ & & & $<0.001$ & 0.031 & $<0.001$ & $<0.001$ & $<0.001$ \\
\hline \multirow[t]{3}{*}{ Perineal laceration } & $n(\%)$ & $1679(24.8)$ & $1060(23.3)$ & $619(27.8)$ & $386(26.2)$ & $158(31.7)$ & $50(30.3)$ & $25(30.1)$ \\
\hline & OR $(95 \% \mathrm{Cl})$ & & & $1.2(1.1-1.3)$ & $1.1(1.0-1.2)$ & $1.4(1.2-1.6)$ & $1.3(1.0-1.6)$ & $1.3(0.9-1.8)$ \\
\hline & $\mathrm{p}$ & & & $<0.001$ & 0.026 & $<0.001$ & 0.038 & 0.147 \\
\hline \multirow[t]{3}{*}{ Pathological CTG } & $n(\%)$ & 765 & 448 & 317 & 183 & 82 & 31 & 21 \\
\hline & OR $(95 \% \mathrm{Cl})$ & & & $1.3(1.1-1.5)$ & $1.2(1.0-1.4)$ & $1.4(1.1-1.7)$ & $1.4(1.0-2.0)$ & $1.7(1.1-2.6)$ \\
\hline & $\mathrm{p}$ & & & $<0.001$ & 0.033 & 0.005 & 0.041 & 0.013 \\
\hline \multirow[t]{3}{*}{ Induction of labour } & $n(\%)$ & $2568(21.5)$ & $1442(18.7)$ & $1126(26.6)$ & $637(24.2)$ & $299(29.4)$ & $113(30.5)$ & $77(36.3)$ \\
\hline & OR $(95 \% \mathrm{Cl})$ & & & $1.4(1.3-1.5)$ & $1.3(1.2-1.4)$ & $1.6(1.4-1.7)$ & $1.6(1.4-1.9)$ & $1.9(1.6-2.3)$ \\
\hline & $p$ & & & $<0.001$ & $<0.001$ & $<0.001$ & $<0.001$ & $<0.001$ \\
\hline \multirow[t]{2}{*}{$\begin{array}{l}\text { Gestational age } \\
\text { of delivery }\end{array}$} & $\begin{array}{l}\text { weeks + days } \\
\text { (n) }\end{array}$ & $38 .+3(11939)$ & $38 .+3(7712)$ & $38 .+2(4227)$ & $38 .+2(2628)$ & $38 .+2(1017)$ & $38 .+2(370)$ & $38 .+4(212)$ \\
\hline & $p$ & & & $>0.05$ & $>0.05$ & $>0.05$ & $>0.05$ & $>0.05$ \\
\hline \multirow[t]{2}{*}{ Preterm delivery } & $\%(n)$ & $19.6(2341)$ & 19.4 (1496) & $20.0(845)$ & 20.1 (527) & $20.7(211)$ & $19.7(73)$ & $16.0(34)$ \\
\hline & $\mathrm{p}$ & & & $>0.05$ & $>0.05$ & $>0.05$ & $>0.05$ & $>0.05$ \\
\hline
\end{tabular}

cially compounded by diabetes and an essential risk for obese women.

Thus, this study shows greatly enhanced delivery risks for obese women. One may speculate that a more restrained management of delivery for obese patients is recommended.

Interestingly, the obstetric emergency of shoulder dystocia was not increased in obese women in this study, which is in contrast to previous findings [25]. The high rate of elective C-sections in obese women in this study might have selected cases at risk and therefore lowered number of cases.

In addition to enhanced maternal risks, newborns of obese mothers suffer from elevated rates of hypoglycemia and asphyxia, as demonstrated in this study. Consequently, newborns of mothers having a BMI $>30 \mathrm{~kg} / \mathrm{m}^{2}$ were more often admitted to the pediatric care unit for further treatment.

Analogous to previous studies [26], the analysis of birth weight showed $90 \%$ (for BMI $>25 \mathrm{~kg} / \mathrm{m}^{2}$ ) more macrosomal newborns with a higher mean birth weight from obese mothers, which might be linked to the previously mentioned increase in gestational diabetes in obese women.
In contrast to previous studies [27,28], there was no elevation of either stillbirths or major malformations of newborns from obese mothers. Successful prenatal care might have lowered the risk of stillbirths, which might also be reflected by the increase in elective C-sections in this study.

The slight decrease in $\mathrm{pH}$-values from the umbilical cord (7.31 vs. 7.32) and the Apgar values (MG 9.42 vs. 9.30) were statistically significant, but their clinical relevance in this dimension is debatable.

In summary, an increased maternal BMI is an essential obstetric risk factor. Enhanced risks are present not only for obese women but also for newborns of obese mothers who may suffer from enhanced perinatal complications as well.

\section{Limitations of this study}

For an analysis of further development of newborns after admission to a pediatric care unit and a possible connection to maternal obesity, a standardized system of obstetric and neonatal data would be useful. In contrast to Scandinavian countries, this has not been established in Germany to date. 
- Table 3 Neonatal outcome of newborns of obese mothers.

\begin{tabular}{|c|c|c|c|c|c|c|c|c|}
\hline & & \multirow{2}{*}{$\begin{array}{l}\text { Total } \\
(n=11939)\end{array}$} & \multicolumn{6}{|l|}{ BMI $\left(\mathbf{k g} / \mathbf{m}^{2}\right)$} \\
\hline & & & $\begin{array}{l}\text { Control group } \\
\text { BMI } \\
18.5-24.9 \\
(n=7712)\end{array}$ & $\begin{array}{l}\text { General obesity } \\
\text { BMI } \geq 25 \\
(n=4227)\end{array}$ & $\begin{array}{l}\text { Overweight } \\
25-29.9 \\
(n=2628)\end{array}$ & $\begin{array}{l}\text { Obesity } I^{\circ} \\
30-34.9 \\
(n=1017)\end{array}$ & $\begin{array}{l}\text { Obesity }{ }^{\circ}{ }^{\circ} \\
35-39.9 \\
(n=370)\end{array}$ & 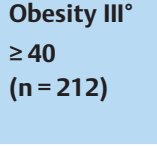 \\
\hline \multirow[t]{3}{*}{ Hypoglycemia } & $\mathrm{n}(\%)$ & $55(0.4)$ & $28(0.3)$ & $27(0.6)$ & $15(0.5)$ & $8(0.8)$ & $3(0.8)$ & $1(0.5)$ \\
\hline & OR $(95 \% \mathrm{Cl})$ & & & $1.8(1.0-3.0)$ & $1.6(0.8-2.9)$ & $2.2(1.0-4.7)$ & $2.2(0.7-7.3)$ & $1.3(0.2-9.5)$ \\
\hline & $\mathrm{P}$ & & & 0.033 & 0.153 & 0.063 & 0.168 & 0.544 \\
\hline \multirow{3}{*}{$\begin{array}{l}\text { Admission to } \\
\text { neonatal care unit }\end{array}$} & $n(\%)$ & $2453(19.6)$ & $1528(18.9)$ & 925 (20.9) & $546(19.9)$ & $231(21.7)$ & $98(25.3)$ & $50(22.6)$ \\
\hline & OR $(95 \% \mathrm{Cl})$ & & & $1.1(1.0-1.2)$ & $1.0(1.0-1.1)$ & $1.1(1.0-1.3)$ & $1.3(1.1-1.6)$ & $1.2(0.9-1.5)$ \\
\hline & $\mathrm{P}$ & & & 0.008 & 0.292 & 0.031 & 0.002 & 0.169 \\
\hline Apgar (5 min) & $\mathrm{MV} \pm \mathrm{SD}$ & $9.38 \pm 1.41$ & $9.42 \pm 1.36$ & $9.30 \pm 1.49$ & $9.31 \pm 1.55$ & $9.22 \pm 1.05$ & $9.43 \pm 1.05$ & $9.45 \pm 0.75$ \\
\hline Apgar (10 min) & $M V \pm S D$ & $9.65 \pm 1.33$ & $9.67 \pm 1.30$ & $9.62 \pm 1.39$ & $9.60 \pm 1.46$ & $9.57 \pm 1.45$ & $9.73 \pm 0.88$ & $9.81 \pm 0.46$ \\
\hline $\begin{array}{l}\text { Venous umbilical } \\
\text { cord-pH } 1\end{array}$ & $\mathrm{MV} \pm \mathrm{SD}$ & $7.31 \pm 0.07$ & $7.32 \pm 0.07$ & $7.31 \pm 0.07$ & $7.31 \pm 0.07$ & $7.31 \pm 0.08$ & $7.31 \pm 0.08$ & $7.30 \pm 0.07$ \\
\hline \multirow[t]{3}{*}{ Stillbirth } & $\mathrm{n}(\%)$ & $147(1.2)$ & $85(1.1)$ & $62(1.4)$ & $42(1.5)$ & $18(1.7)$ & $2(0.5)$ & $0(0.0)$ \\
\hline & OR $(95 \% \mathrm{Cl})$ & & & $1.3(1.0-1.8)$ & $1.5(1.0-2.1)$ & $1.6(1.0-2.7)$ & $0.5(0.1-2.0)$ & \\
\hline & $\mathrm{P}$ & & & 0.084 & 0.046 & 0.064 & 0.440 & \\
\hline \multirow{3}{*}{$\begin{array}{l}\text { Major } \\
\text { malformations }\end{array}$} & $\mathrm{n}(\%)$ & $486(3.7)$ & $304(3.8)$ & $164(3.7)$ & $106(3.9)$ & $34(3.2)$ & $16(4.1)$ & $8(3.6)$ \\
\hline & OR $(95 \% \mathrm{Cl})$ & & & $1.0(0.8-1.2)$ & $1.0(0.8-1.3)$ & $0.8(0.6-1.2)$ & $1.1(0.7-1.8)$ & $1.0(0.5-1.9)$ \\
\hline & $\mathrm{P}$ & & & 0.886 & 0.837 & 0.353 & 0.720 & 0.909 \\
\hline \multirow[t]{3}{*}{ Macrosomia } & $\mathrm{n}(\%)$ & $140(1.1)$ & $68(0.8)$ & $72(1.6)$ & $34(1.2)$ & $21(2.0)$ & $9(2.3)$ & $8(3.6)$ \\
\hline & OR $(95 \% \mathrm{Cl})$ & & & $1.9(1.4-2.7)$ & $1.5(1.0-2.2)$ & $2.3(1.4-3.8)$ & $2.8(1.4-5.5)$ & $4.3(2.1-8.8)$ \\
\hline & $\mathrm{p}$ & & & $<0.001$ & 0.065 & $<0.001$ & 0.008 & $<0.001$ \\
\hline Birth weight & $g(M V \pm S D)$ & $3120 \pm 798$ & $3087 \pm 768$ & $3179 \pm 847$ & $3159 \pm 844$ & $3181 \pm 865$ & $3211 \pm 791$ & $3087 \pm 768$ \\
\hline \multirow[t]{3}{*}{ Asphyxia } & $\mathrm{n}(\%)$ & $7(0.1)$ & $1(0.0)$ & $6(0.1)$ & $4(0.1)$ & $2(0.2)$ & $0(0.0)$ & $0(0.0)$ \\
\hline & OR $(95 \% \mathrm{Cl})$ & & & $10.9(1.3-90.9)$ & $11.7(1.3-104.9)$ & $15.2(1.4-167.1)$ & & \\
\hline & $\mathrm{P}$ & & & 0.010 & 0.017 & 0.38 & & \\
\hline \multirow[t]{3}{*}{ IUGR } & $\mathrm{n}(\%)$ & 466 (3.9) & $279(3.5)$ & $187(4.2)$ & $118(4.3)$ & $48(4.5)$ & $10(2.6)$ & $11(5.0)$ \\
\hline & OR $(95 \% \mathrm{Cl})$ & & & $1.2(1.0-1.5)$ & $1.2(1.0-1.5)$ & $1.3(1.0-1.8)$ & $0.7(0.4-1.4)$ & $1.4(0.8-2.6)$ \\
\hline & P & & & 0.030 & 0.045 & 0.082 & 0.351 & 0.225 \\
\hline
\end{tabular}

Furthermore, this study is limited by its retrospective design. This led to incomplete data for $n=599$ patients, which could indicate a risk for selection bias. Moreover, it is a unicentric study, and possible transferability to other regions or countries must be evaluated. Additionally, screening for gestational diabetes was performed in Germany before 2011 mainly by testing urine for glucose, which has a risk of false negative results. Hence, the prevalence of gestational diabetes may be higher than reported by this study.

\section{Conclusion}

Maternal obesity is an essential obstetric risk factor which becomes even more important in the future. Obese mothers suffer from high rates of non-elective C-sections, and newborns face a higher risk for postpartal hypoglycaemia depending on maternal BMI. Obese and overweight (BMI $25-30 \mathrm{~kg} / \mathrm{m}^{2}$ ) women planning a pregnancy need to be educated about increased risks which come with an elevated BMI. These patients should be encouraged to reduce weight before becoming pregnant. 


\section{Acknowledgments}

The authors would like to thank Prof. König, Institute of Medical Biometry and Statistics, University of Lübeck, for the support of the statistical analysis.

Conflict of Interest

The authors declare that they have no conflict of interest.

\section{References}

[1] Berrington de Gonzalez A, Hartge P, Cerhan JR et al. Body-mass index and mortality among 1.46 million white adults. N Engl J Med 2010; 363: 2211-2219; Erratum in: N Engl J Med 2011; 365: 869

[2] Pischon T, Boeing H, Hoffmann $\mathrm{K}$ et al. General and abdominal adiposity and risk of death in Europe. N Engl J Med 2008; 359: 2105-2120; Erratum in: N Engl J Med 2010; 362: 2433

[3] Mensink GBM, Schienkiewitz A, Haftenberger $M$ et al. Übergewicht und Adipositas in Deutschland: Ergebnisse der Studie zur Gesundheit Erwachsener in Deutschland (DEGS1). Bundesgesundheitsblatt 2013; 56: 786-794

[4] Cedergren MI. Maternal morbid obesity and the risk of adverse pregnancy outcome. Obstet Gynecol 2004; 103: 219-224

[5] Sebire NJ, Jolly M, Harris JP et al. Maternal obesity and pregnancy outcome: a study of 287,213 pregnancies in London. Int J Obes Relat Metab Disord 2001; 25: 1175-1182

[6] Aydin C, Baloglu A, Yavuzcan A et al. The effect of body mass index value during labor on pregnancy outcomes in Turkish population (obesity and pregnancy outcomes). Arch Gynecol Obstet 2010; 281: 49-54

[7] Ben-Haroush A, Hadar E, Chen R et al. Maternal obesity is a major risk factor for large-for-gestational-infants in pregnancies complicated by gestational diabetes. Arch Gynecol Obstet 2009; 279: 539-543

[8] García-Patterson A, Aulinas A, María MÁ et al. Maternal body mass index is a predictor of neonatal hypoglycemia in gestational diabetes mellitus. J Clin Endocrinol Metab 2012; 97: 1623-1628

[9] Rozance PJ. Update on neonatal hypoglycemia. Curr Opin Endocrinol Diabetes Obes 2014; 21: 45-50

[10] Arrowsmith S, Wray S, Quenby S. Maternal obesity and labour complications following induction of labour in prolonged pregnancy. BJOG 2011; 118: $578-588$

[11] Zhang J, Bricker L, Wray $S$ et al. Poor uterine contractility in obese women. BJOG 2007; 114: 343-348

[12] Roloff K, Peng S, Sanchez-Ramos L et al. Cumulative oxytocin dose during induction of labor according to maternal body mass index. Int J Gynaecol Obstet 2015; 131: 54-58
[13] Suidan RS, Rondon KC, Apuzzio || et al. Labor outcomes of obese patients undergoing induction of labor with misoprostol compared to dinoprostone. Am J Perinatol 2015; 30: 187-192

[14] Quenby S, Pierce SJ, Brigham S et al. Dysfunctional labor and myometrial lactic acidosis. Obstet Gynecol 2004; 103: 718-723; Erratum in: Obstet Gynecol 2004; 103: 1344

[15] Quenby S, Pierce S], Brigham S et al. Dysfunctional labor and myometrial lactic acidosis. Obstet Gynecol 2004; 103: 718-723

[16] Carlson NS, Hernandez TL, Hurt KJ. Parturition dysfunction in obesity: time to target the pathobiology. Reprod Biol Endocrinol 2015; 13: 135

[17] Poobalan AS, Aucott LS, Gurung T et al. Obesity as an independent risk factor for elective and emergency caesarean delivery in nulliparous women-systematic review and meta-analysis of cohort studies. Obes Rev 2009; 28-35

[18] Arbeitsgemeinschaft der Wissenschaftlichen Medizinischen Fachgesellschaften e.V. - AWMF. AWMF-Leitlinien-Register: Betreuung von Neugeborenen diabetischer Mütter Nr (024/006). 2010. Online: http:// www.awmf.org/uploads/tx_szleitlinien/024-006_S2k_IDA_Betreuung_ von_Neugeborenen_diabetischer_Muetter_05-2010_05-2015_01.pdf; last access: 15.12.2014

[19] Voigt M. Methodische Aspekte für die Berechnung von Normwertkurven für das Geburtsgewicht. 120. Tagung NGGG, Rostock 2004: Poster 50"

[20] Kabiru W, Raynor BD. Obstetric outcomes associated with increase in BMI category during pregnancy. Am J Obstet Gynecol 2004; 191: 928932

[21] Hänseroth K, Distler W, Kamin G et al. Schwangerschaftsverlauf, Geburt und Wochenbett bei adipösen Frauen. Geburtsh Frauenheilk 2007; 67: 33-37

[22] Weiss JL, Malone FD, Emig D. Obesity, obstetric complications and cesarean delivery rate - a population-based screening study. Am J Obstet Gynecol 2004; 190: 1091-1097

[23] Abenhaim HA, Kinch RA, Morin L et al. Effect of prepregnancy body mass index categories on obstetrical and neonatal outcomes. Arch Gynecol Obstet 2007; 275: 39-43

[24] Mylonas I, Friese K. The indications for and risks of elective cesarean section. Dtsch Arztebl Int 2015; 112: 489-495

[25] Crane JM, Murphy P, Burrage L et al. Maternal and perinatal outcomes of extreme obesity in pregnancy. J Obstet Gynaecol Can 2013; 35: 606611

[26] Tita AT, Landon MB, Spong CY et al. Timing of elective repeat cesarean delivery at term and neonatal outcomes. N Engl J Med 2009; 360: 111 120

[27] Schaefer UM, Songster G, Xiang A et al. Congenital malformations in offspring of women with hyperglycemia first detected during pregnancy. Am J Obstet Gynecol 1997; 177: 1165-1171

[28] Stothard KJ, Tennant PW, Bell R et al. Maternal overweight and obesity and the risk of congenital anomalies: a systematic review and meta-analysis. JAMA 2009; 301: 636-650 